\title{
薬物ナノ結晶を基盤とした眼内薬物送達システム
}

\author{
長井紀章
}

\section{Ocular Drug Delivery System-based on Solid Nanoparticles}

\author{
Noriaki Nagai \\ Faculty of Pharmacy, Kindai University; 3-4-1 Kowakae, Higashi-Osaka, Osaka 577-8502, Japan.
}

(Received August 16, 2020)

\begin{abstract}
The use of eye drops is a well-established practice in the treatment of ophthalmic diseases, although the bioavailability of traditional eye drops, which are either solutions or suspensions, is insufficient, as the corneal barrier and dilution by lacrimation prevent the transcorneal penetration of drugs. Additionally, frequent instillation may cause undesirable systemic side effects and local corneal toxicity. To overcome these problems, micro- and nanoparticles, hydrogels, and viscous solutions have been tested, and solid nanoparticles are also expected to be applied. This review examines the usefulness of ophthalmic formulations based on solid nanoparticles, by using the specific example of indomethacin (IMC) . Ophthalmic formulations based on solid IMC nanoparticles (IMC-NP dispersions) have been prepared using various additives (benzalkonium chloride, mannitol, methylcellulose, and cyclodextrin) and a rotation/revolution pulverizer (NP-100), to produce particles of 50-220 nm in size. The solubility of IMC in IMC-NP dispersions was 4.18-fold higher than that in the suspensions containing IMC microparticles (IMC-MP suspensions), and IMC-NP dispersions were better tolerated than commercially available NSAIDs eye drops, such as IMC, pranoprofen, diclofenac, bromfenac, and nepafenac eyedrops, in human corneal epithelial cells. Moreover, the corneal penetration in IMC-NP dispersions was higher than that in commercially available IMC and IMC-MP suspensions, and three energy-dependent endocytosis pathways (clathrin-dependent endocytosis, caveolae-dependent endocytosis, and macropinocytosis) were related to the high ophthalmic bioavailability of IMC-NP dispersions. This information can be used to support future studies aimed at designing novel ophthalmic formulations.
\end{abstract}

Key words—_ nanoparticle; drug delivery; ophthalmic formulation; indomethacin; endocytosis

\section{1. はじめに}

点眼薬は安全性や利便性の面から現在臨床にて広 く受け入れられており，眼疾患治療の第一選択とさ れている。一方, 点眼された薬物は涙液により希釈 され，鼻涙管を通じて短時間（10 分以内）で眼表 面から洗い流される。また，点眼薬が眼内組織（毛 様体や水晶体など）で薬効を発現するためには，薬 物が薬物透過に対するバリアとして機能している角 膜を透過し眼房水中に移行する必要がある。このた め眼内組織を標的とした薬物治療には，点眼後の薬 物滞留性向上や角膜の薬物通過性を高め, 眼内への 効果的な薬物供給を可能とする工夫が必要である.

近畿大学薬学部（广577-8502 大阪府東大阪市小若江 34-1)

e-mail: nagai_n@phar.kindai.ac.jp

本総説は, 日本薬学会第 140 年会シンポジウム S02 で 発表した内容を中心に記述したものである.
これら課題を解決すべく，粘性ポリマー溶液，ハイ ドロゲル, リポソームやナノパーティクルなど様々 な技術が研究されており，今後これら剂形の適用に より, 既存の点眼薬の効能が十分に引き出されるこ とが期待される．筆者もこれら点眼薬の機能向上に 向け，ナノ結晶を基盤とした製荗設計について研究 を進めてきた. ${ }^{1-3)}$ その結果, 懸濁分散液中の薬物 粒子サイズを数十ナノ〜数百ナノの間で制御するこ とで, 薬物の角膜や結膜への付着・滞留性が変化す ることを見い出した。 ${ }^{4)}$ また，薬物超微粒子（100 $\mathrm{nm}$ 以下）を点眼した際には，角膜上でエネルギー 依存的な膜透過機構が働き, 従来の溶液型や懸濁型 点眼薬と比較し, 高い薬物眼内移行が得られること を示してきた. ${ }^{4)}$ 本稿では，近年，製剤の品質と機 能の向上に著しく貢献することが期待されているナ ノ技術（ナノテクノロジー）を基盤とした新しい点 眼システム「ナノ結晶点眼製剤」の調製法について 


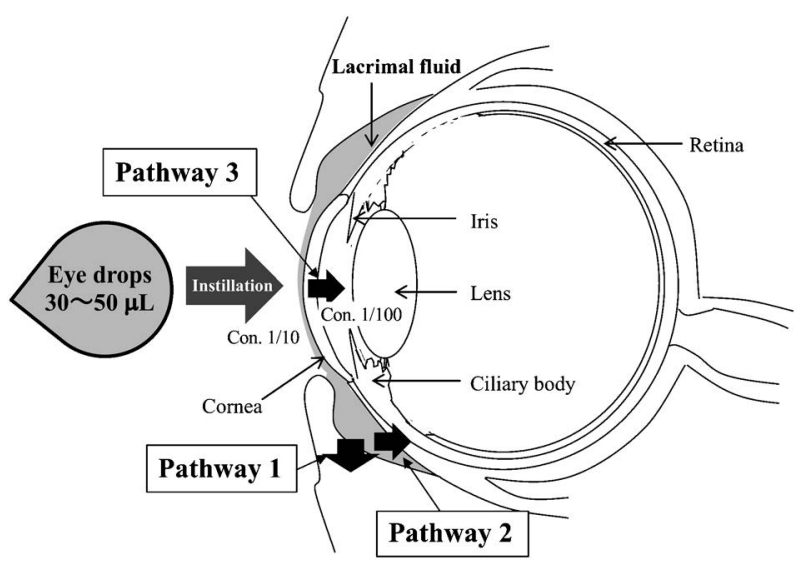

Fig. 1. Drug Behavior after the Instillation on the Ocular Surface

紹介するとともに，これらナノ結晶点眼製剤の眼内 移行メカニズムについて概説する.

\section{2. 点眼薬点眼後の薬物体内分布}

眼球表面（結膜囊）における沪液保持用量は動物 種の違いにより異なるが, 人の場合は約 $30 \mu \mathrm{L}$ とさ れている。このため, 点眼量を高めても， $30 \mu \mathrm{L}$ （最大保持用量）以上の薬液は眼外へあふれでる. 眼表面で保持された点眼液は，次の 3 つの経路 （pathway 1-3）を介し体内・眼内へ移行する（Fig. 1)..$^{5-7)}$

まず 1 つ目は「涙点から涙液とともに排出され, 鼻腔や咽頭，消化管から吸収され全身循環へ移行す る」経路（pathway 1) である．涙腺から分泌され た涙液は，瞬きにより内眼角部（目頭）に集まり， その後上下にある涙点に入り, 涙小管, 涙囊, 鼻涙 管を通って鼻腔から咽頭部，消化管へ流れる．点眼 後の薬物もまた，同経路にて消化管へと流れる．こ のため, 点眼液は消化管だけでなく鼻腔粘膜又は咽 頭粘膜からも吸収され，全身循環入る。点眼後の全 身への薬物吸収率は点眼薬物の 1-35\%といわれ， 血清，血漿，副腎，胆囊，胆汁，尿，腎臓，肝臓な ど全身に到達すると考えられている．多くの市販点 眼液は約 0.1-1\%の濃度に調整されており，1 回点 眼後の血中濃度は $\mathrm{ng} / \mathrm{mL}$ レベルである. ${ }^{5-7)}$

2つ目は「結膜や眼瞼の脈管系より全身循環へ移 行する」経路（pathway 2) である。結膜上皮に吸 収された薬物は，強膜の眼内側は血管に富んだぶど う膜により吸収され，大部分が血管を介して全身循 環へ移行する，このため，この結膜経由経路により 点眼投与された薬物が, 眼内に到達することは少な
いと考えられている. ${ }^{5-7)}$

最後の 3 つ目は「角膜を通り, 眼球内部から後部 へ移行する」経路（pathway 3) である．角膜には 血管が存在せず，角膜に吸収された薬物は前房部の 虹彩や水晶体に到達する。 また，前房部に到達した 点眼液の一部はぶどう膜強膜流出により毛様体，脈 絡膜, 網膜（視神経乳頭部）にまで到達する. ${ }^{5-7)}$ この角膜経由ルートである pathway 3 が点眼薬点 眼後の眼内移行の主たる経路であり，薬物の眼内移 行量を決める重要な因子である.

Pathway 3 において, 点眼液はもともと存在する 涙液量と点眼による刺激で新たに分泌された涙液と 混じり，眼表面ではもともとの濃度の約 $1 / 10$ まで 希釈される.さらに希釈された点眼液が角膜を通過 して眼内に移行する量はより少なく, もともとの 1 / 100 程度といわれている.

\section{3. 薬物滞留性・眼内移行性の向上を目的とした} 臨床で用いられる製剂工夫

先に示した通り，点眼薬は局所だけで作用するの ではなく, 全身にも移行するため, 薬理作用が強い ものでは循環器系や呼吸器系など全身への影響（副 作用）がみられる.このため, 点眼薬のバイオアベ イラビリティ（bioavailability; BA）を高めるため には，点眼液中の薬物含量を単に高めるといつた副 作用増大につながる方法ではなく, 眼表面での薬物 滞留性や薬物角膜透過性の向上を目的とした工夫が 必要である. 現在市販点眼薬にて最も一般的な工夫 は増粘剤の使用である。主な眼科用増粘剤として は，メチルセルロース，ヒドロキシエチルセルロー ス，ポリビニルピロリドン， ポリビニルアルコー ル，ヒドロキシプロピルメチルセルロースのような 半合成高分子，カルボキシビニルポリマーのような 合成高分子，アルギン酸，コンドロイチン硫酸ナト リウムのような天然高分子が用いられている。 これ ら点眼製剂の粘性を高めることで，点眼後の外眼部 滞留性が高まり, 結果として徐放化と BA 向上につ ながるといつた製剤工夫がなされている。なかでも 可逆的ゾルーゲルの相転移特性を有するメチルセル ロースは，眼表面温度付近でゲル化することによ り，持続性向上が得られる。これら in situ gelling system といわれる製剂工夫からなる代表的な点眼 製剤としては市販リズモン ${ }^{\circledR} \mathrm{TG}$ 点眼薬（熱応答ゲ ル製剂）が挙げられる。一方，これら増粘剤を用い 


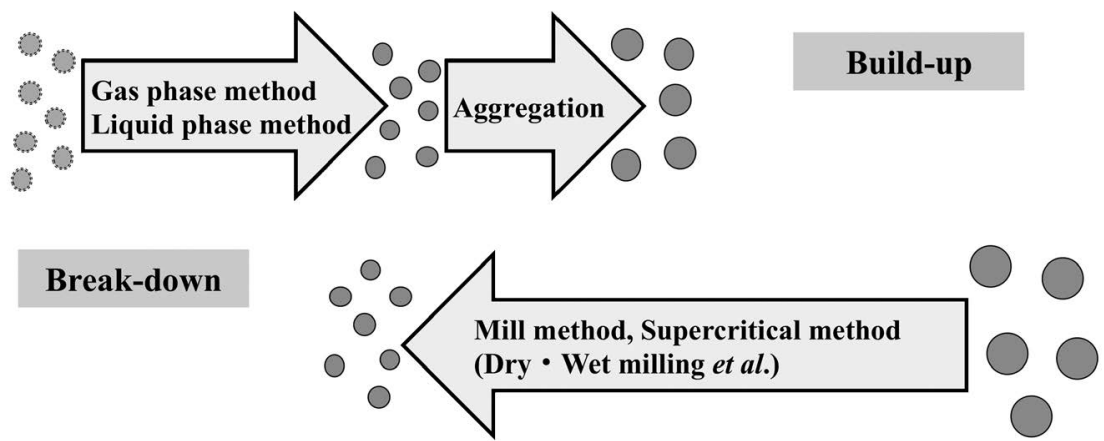

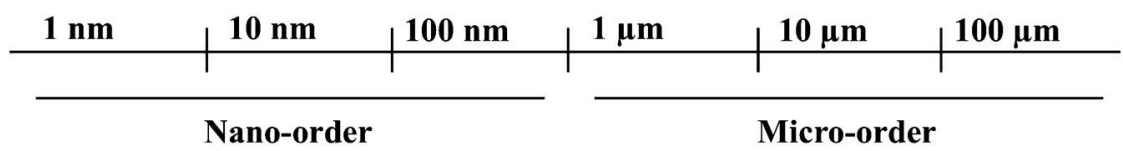

Fig. 2. Schematic Representation Showing Build-up and Break-down Methods to Prepare the Nanoparticles

た工夫は，点眼製剤の眼表面の滞留性を高めること を目的としており，眼内への薬物移行量の促進は二 次的なものである.このため, 薬物滞留性及び角膜 透過性の両方を達成する製剂工夫の実現が近年期待 されている.

\section{4. ナノ結晶医薬品の特徵}

ナノメートル単位の微細加工技術，原子や分子を 1 個ずつ操作する技術, 微細な構造を計測する技術 及びこれらの構造を形成する材料技術を用いて，ナ ノメートルサイズの構造を作るための技術の総称を ナノテクノロジーという。ナノテクノロジーが注目 される背景には粒子サイズにより体内での薬物動態 挙動が異なることが挙げられ，一般にナノ粒子を注

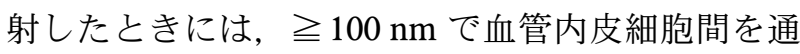
過し， ミ200 nm では脾蔵にて処理される。また, ミ300-400 nm ではマクロファージにより捕捉・排 出され， $\geqq 2 \mu \mathrm{m}$ になると肝臓細胞に取り込まれる といった特性が知られている。 ${ }^{8-10)}$ さらに, 200-300 nm 程度又はそれ以上の粒子のサイズでは溶解度の変化 はほとんど期待できないが，超微細化により粒子径 を $100 \mathrm{~nm}$ 以下にすることで, 薬物溶解度の改善も 期待できる. 加えて, ナノ粒子は, 細胞間隙に対し 高い付着性を示し, 薬物膜透過性や滞留性の充進に つながることから，眼科領域においても，ナノテク ノロジーの特性を利用したドラッグデリバリーシス テム（drug delivery system; DDS）製剤の開発が期 待されている.

\section{5. ナノ結晶の製造法}

一般に, 薬学・医学領域におけるナノ粒子はサブ
ミクロン以下のサイズの粒子を指し，これらナノ粒 子の作製手法として大きくビルドアップ法とブレイ クダウン法の 2 つに分類できる（Fig. 2)．貧溶媒 （アンチソルベント）法, 晶析法, 噴霧乾燥装置な どを利用したナノ粒子の作製手法をビルドアップ法 といい, 分子レベルの原薬をナノサイズに至るまで 成長させる方法を指す。一方, 超臨界法や遊星型粉 砕法といつた粉砕報 (ビーズミルやボールミルなど) をブレイクダウン法といい, 原薬をナノサイズまで 粉砕する方法である. 通常, ビルドアップ法と比較 しブレイクダウン法にて得られた粒子の方が, 安定 性が高く, 加工が容易で量産性に優れていることか ら, ブレイクダウン法が難溶解性化合物のナノ結晶 化に用いられることが多い.しかし，ブレイクダウ ン法で製造できるナノ結晶のサイズは 200-300 nm 程度と, Ostwald-Freudlich 式から予想されるよう に溶解度改善が得られる $100 \mathrm{~nm}$ 以下のナノ結晶調 製は困難とされている。 これら課題を解決すべく, 筆者はこれまで難溶解性薬物インドメタシンなどを モデル薬物として，ブレイクダウン法 (湿式破砕法) の破砕効率向上を可能とする新処方を模索してき た. ${ }^{11,12)}$ 一般にナノ結晶の調製に用いられてる添加 物として, polyvinylpyrrolidone, 水溶性ポリマー hydroxypropyl cellulose，イオン性界面活性剤（sodium dodecyl sulfate, docusate sodium), 非イオン 性界面活性剂（poloxamer, tween80）が知られてい る.これら添加物はナノ結晶調製において非常に重 要であるが, 筆者は, 湿式破砕法による薬物ナノ結 晶粒子の作製にはシクロデキストリンとセルロース 
A
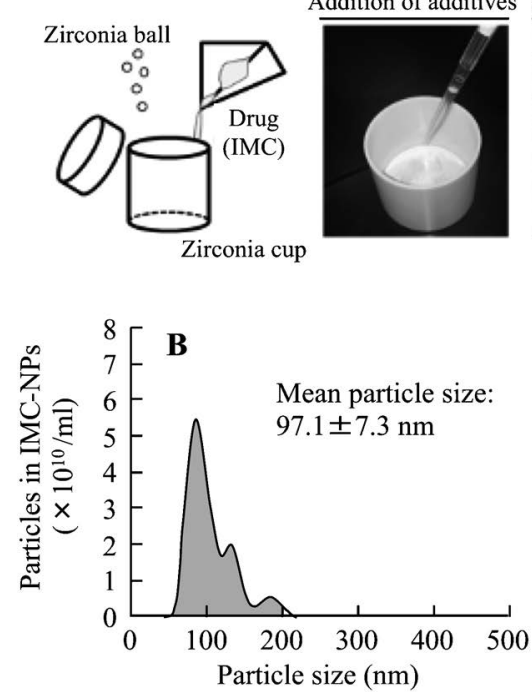

Addition of additives Set on the NP-100 Remove the ball by filtration
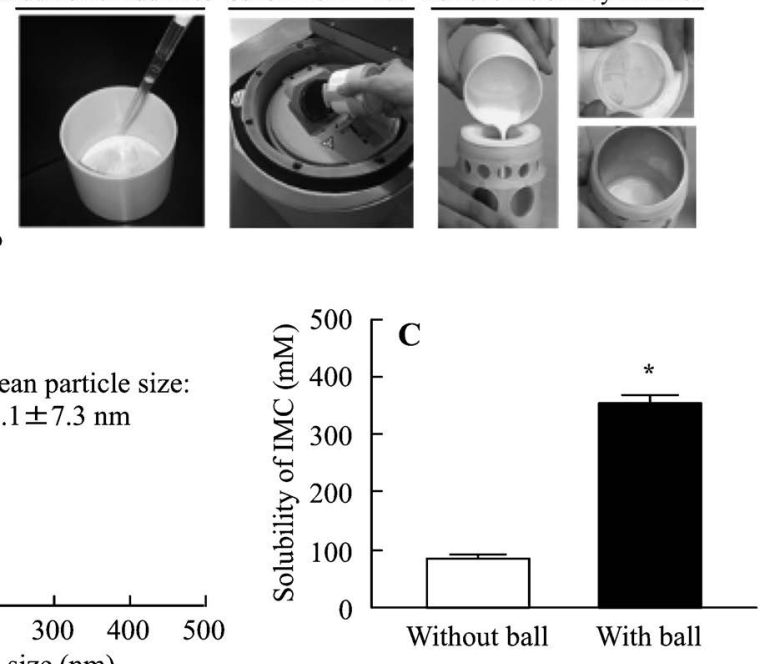

Fig. 3. Preparation of Drug Nanoparticles by the Rotation/Revolution Pulverizer (NP-100)

A, Preparation procedures of ophthalmic dispersions containing IMC nanoparticles. B, Particle distribution of IMC-NPs by the NanoSight LM10. C, Solubility of IMC in IMC-NPs dispersions. The data represent the means \pm S.E. of 5 experiments. ${ }^{*} p<0.05 v s$. with ball mill (unpaired student's $t$-test).

誘導体（メチルセルロースなど）の添加が特に重要 であることを明らかとした. ${ }^{12)}$ さらに本法において シクロデキストリンを添加することで， シクロデキ ストリンが薬物粒子の表面に付着し，コーティング のように作用することでナノ粒子分散液の問題点と もいえる凝集性が飛躍的に抑制できることを示し

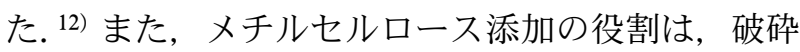
効率の向上であり，非添加にて湿式破砕を行った際 には，難溶解性の薬物（疎水性）と溶媒が混じった メレンゲ様の状態となるが（流動性を有する分散液 とはならない)，メチルセルロースなどセルロース 誘導体を添加することで，効果的な薬物破砕につな がり，平均粒子径 60-200 $\mathrm{nm}$ の良質な薬物ナノ結 晶を含む分散液の調製が可能となる．本研究では代 表的薬物として本法を用いて作製したインドメタシ ンナノ結晶 (indomethacin nanoparticles; IMC-NPs) の粒度分布を示す. Figure 3(A) のように先に示し た添加物を用い，シンキー社製 自転・公転ナノ粉 砕機 NP-100（東京）にて IMC を湿式破砕処理す ることで，粒子径 50-220 nm のナノ結晶が調製で きた [Fig. 3(B)]。これら IMC-NPs は湿式破砕前 に比べて，溶解度が 4.18 倍高まっており [Fig. 3 (C) ] ，この溶解度上昇にはシクロデキストリンに よる包接能増加と $100 \mathrm{~nm}$ 以下の粒子サイズに伴う 薬物自体の溶解度の上昇の両方が係わっていた. ${ }^{12)}$

\section{6. ナノ結晶含有点眼液の角膜傷害性}

薬剂性角膜症は眼局所における点眼薬の副作用の 1つであり，これら点眼による角膜障害は，患者の アドヒアランスの低下につながる，そこで近年の眼 科領域では，目に優しい点眼薬として，角膜傷害性 の低い製剂処方や剂形の開発が試みられている。今 回，ヒト角膜上皮細胞を用い，先の方法で調製した IMC-NPs と他の市販 NSAIDs 点眼液の角膜傷害性 を比較評価したところ，IMC-NPs の角膜細胞傷害 性は，従来型である溶液型 NSAIDs 点眼液と比較 し，顕著に低值であった（Fig. 4）。この低毒性の 理由には，ナノ結晶製剂は薬物を溶解する必要がな いため，市販製剤のように界面活性剂の添加が不要 であること（安全な溶媒の使用が可能），さらに溶 液状態の薬物と比較し, 結晶状態では細胞表面に対 する影響が少ないことなどが考えられる。 ${ }^{12)}$

\section{7. ナノ結晶含有点眼薬の角膜透過性}

ウサギ摘出角膜を角膜透過セルに設置した in vitro 角膜透過実験にて IMC-NPs の角膜透過性に ついて検討した。その結果，実験開始 6 時間後にお いて，IMC-NPs はマイクロ粒子からなる IMC 分 散液（IMC microparticles；IMC-MPs）や従来の溶 液型 IMC 点眼製剤（CA-IMC）と比較し，それぞ れ 2.24，3.41 倍高い角膜透過量が得られた. 12) これ らナノ粒子の高い膜透過機構を把握することは重要 であり，ナノ粒子が生体膜に付着した際にはエンド 


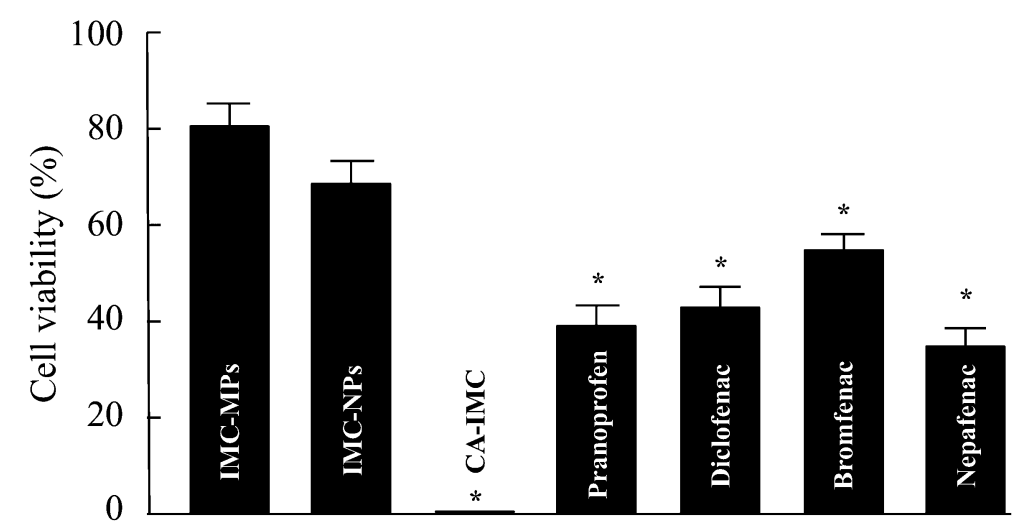

Fig. 4. Cell Viability in the Human Corneal Epithelial Cell (HCE-T) Treated with Ophthalmic Formulations for $120 \mathrm{~s}$

Ophthalmic dispersions containing IMC microparticles and nanoparticles were presented as IMC-MPs and IMC-NPs, respectively, and the commercially available IMC (CA-IMC), pranoprofen, diclofenac, bromfenac, nepafenac were used. The data represent the means \pm S.E. of 5-10 experiments. ${ }^{*} p<0.05 v s$. IMCNPs (Dunnett's multiple comparison).
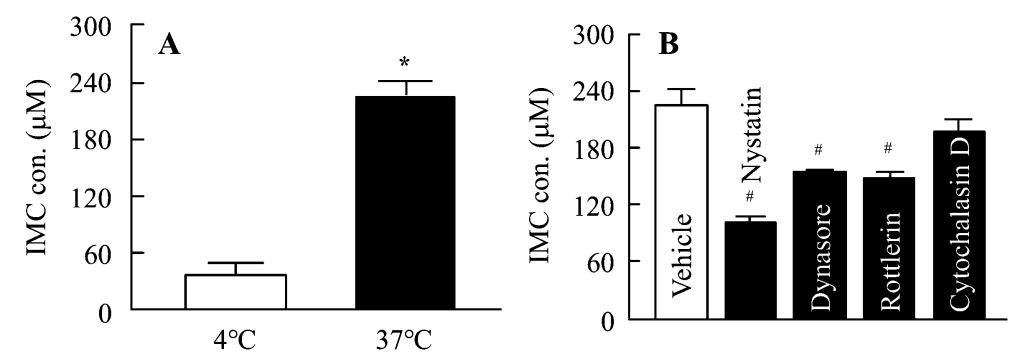

Fig. 5. Effect of Endocytosis on the Transcorneal Penetration of IMC-NPs Using Isolated Rabbit Cornea

The experiments were performed for $6 \mathrm{~h}$ by using a methacrylate cell designed for transcorneal penetration studies. The energy dependent endocytosis was prevented under the $4^{\circ} \mathrm{C}$ condition, and each endocytosis pathway was inhibited by the treatment of $54 \mu \mathrm{M}$ nystatin, $40 \mu \mathrm{M}$ dynasore, $2 \mu \mathrm{M}$ rottlerin or $10 \mu \mathrm{M}$ cytochalasin D. The data represent the means \pm S.E. of 5-8 experiments. ${ }^{*} p<0.05 v s .4^{\circ} \mathrm{C}$ condition (Dunnett's multiple comparison). ${ }^{*} p<0.05 v s$. Vehicle (Dunnett's multiple comparison).

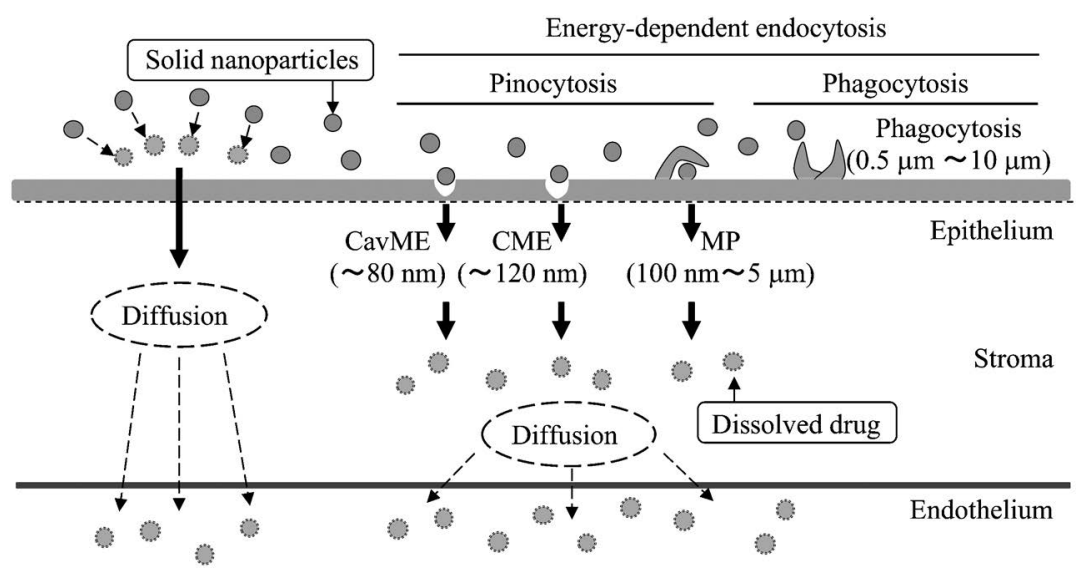

Fig. 6. Schematic Illustration of the Transcorneal Penetration of IMC-NPs via Energy-dependent Endocytosis Pathways

サイトーシスのようなエネルギー依存性の能動的取 り込みが働くことが知られている. ${ }^{13,14)}$ エネルギー 依存性エンドサイトーシスは通常生体内で働く取り 込み機構であり, 大きくカベオラ依存性エンドサイ トーシス，クラスリン依存性エンドサイトーシス,
マクロピノサイトーシスそしてファゴサイトーシス の 4 種類に分類できる. ${ }^{15,16)}$ これまでの研究により, 4 つのエンドサイトーシスは粒子サイズが異なる物 質の取り込みに関与しており, カベオラ依存性エン ドサイトーシスは $80 \mathrm{~nm}$ 以下のくぼみ（カベオラ） 
に粒子が入り込んだ際に働き，クラスリン依存性エ ンドサイトーシスは $120 \mathrm{~nm}$ 以下の粒子が標的とな ることが報告されている。 また， 0.1-5 $\mu \mathrm{m}$ の粒子 に働くマクロピノサイトーシスや，マクロファージ などで働く 0.5-10 $\mu \mathrm{m}$ の粒子の取り込みに係わる

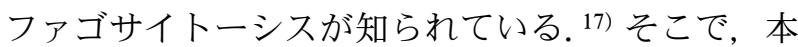
研究ではすべてのエネルギー依存性エンドサイトー シスが阻害できる低温 $\left(4^{\circ} \mathrm{C}\right)$ 条件下 ${ }^{18)}$ 及び各エン ドサイトーシスの阻害剤である nystatin（カベオラ 依存性エンドサイトーシス阻害剤), dynasore（ク ラスリン依存性エンドサイトーシス阻害剤), rottlerin（マクロピノサイトーシス阻害剤），そして cytochalasin D（ファゴサイトーシス阻害剤）をそ れぞれ用い, ${ }^{4,19)}$ ナノ結晶粒子の薬物透過とエンド サイトーシスの関連性について検討を行つた。ま ず，エネルギーを介した細胞内取り込夕機構をすべ て抑えることができる低温 $\left(4^{\circ} \mathrm{C}\right)$ 条件下において 薬物透過性を確認したところ, 顕著な薬物皮膚透過 の低下が認められ [Fig. 5(A) ], IMC-NPs の薬物 皮膚透過にエネルギー依存性エンドサイトーシスが 関与していることが示唆された。次に，阻害剤にて 各エンドサイトーシスの働きを抑制したところ, IMC-NPs では nystatin（カベオラ依存性エンドサ イトーシス阻害剤), dynasore（クラスリン依存性 エンドサイトーシス阻害剤）及び rottlerin（マクロ ピノサイトーシス阻害剂）処理において有意な薬物 透過の低下がみられた [Fig. 5(B)]。今回用いた IMC-NPs の粒度分布は 50-220 nm であり，これら は 3 種のエンドサイトーシスの標的粒子サイズに適 合する。したがって，表皮や表皮組織での IMC ナ ノ粒子サイズがエンドサイトーシスの誘発に関与 し，これらエンドサイトーシスが IMCナノ粒子の 角膜透過（細胞内取り込み）に関与しているものと 考えられた（Fig. 6)。一方，これら疎水性の薬物 分子の集団からなるナノ結晶薬物の取り込み（エン ドサイトーシス）機構についてはいまだ不明であ り，更なる検討が必要である.

\section{8. おわりに}

筆者は，ビーズミル法（ブレイクダウン法）と各 種添加物を組み合わせることで，良質なナノ結晶粒 子を含む分散液の調製法を確立した。また，筆者が 提案したナノ結晶を用いた点眼システムは，従来の 溶液型の製剂と比較し，目に優しく，高い角膜透過
性，持続性を有していることを明らかとした。今回 紹介した “ナノ化技術を基盤とした点眼システム” を始めとする DDS 技術の進歩が点眼薬物療法の発 展につながることを期待する。

\section{謝辞本研究は, 近畿大学薬学部で行われた研} 究であり，実験を行った共同研究者を始め研究室に 在籍した方々に心から感謝いたします。

\section{利益相反＼cjkstart開示すべき利益相反はない.}

\section{REFERENCES}

1) Nagai N., Fukuoka Y., Sato K., Otake H., Taga A., Oka M., Hiramatsu N., Yamamoto N., Int. J. Mol. Sci., 21, pii: E1048 (2020).

2) Nagai N., Ishii M., Seiriki R., Ogata F., Otake H., Nakazawa Y., Okamoto N., Kanai K., Kawasaki N., Pharmaceutics, 12, pii: E155 (2020) .

3) Minami M., Seiriki R., Otake H., Nakazawa Y., Kanai K., Tanino T., Nagai N., Materials (Basel), 13, pii: E1675 (2020).

4) Nagai N., Ogata F., Otake H., Nakazawa Y., Kawasaki N., Int. J. Nanomedicine, 14, 12131227 (2019).

5) Ohman L., Edqvist L. E., Johansson E. D., Acta Ophthalmol. (Copenh.), 60, 106-112 (1982).

6) Janes R. G., Stiles J. F., Am. J. Ophthalmol., 56, 84-90 (1963).

7) Spiess B. M., Nyikos S., Stummer E., Sahin A., Naegeli H., Am. J. Vet. Res., 60, 571-576 (1999) .

8) Dobrovolskaia M. A., Aggarwal P., Hall J. B., McNeil S. E., Mol. Pharm., 5, 487-495 (2008).

9) Toy R., Peiris P. M., Ghaghada K. B., Karathanasis E., Nanomedicine (Lond.), 9, 121-134 (2014).

10) Moribe K., Higashi K., Drug Delivery System, 30, 92-99 (2015).

11) Nagai N., Iwai Y., Sakamoto A., Otake H., Oaku Y., Abe A., Nagahama T., Int. J. Nanomedicine, 14, 7921-7931 (2019).

12) Nagai N., Ito $Y$. , Okamoto N., Shimomura Y., Toxicology, 319, 53-62 (2014).

13) Proulx S. T., Luciani P., Dieterich L. C., 
Karaman S., Leroux J. C., Detmar M., J. Control. Release, 172, 550-557 (2013).

14) Youm I., Bazzil J. D., Otto J. W., Caruso A. N., Murowchick J. B., Youan B. B., AAPS J., 16, 550-567 (2014).

15) Rappoport J. Z., Biochem. J., 412, 415-423 (2008).

16) Wang J., Byrne J. D., Napier M. E., Desimone J. M., Small, 7, 1919-1931 (2011).
17) Zhang S., Li J., Lykotrafitis G., Bao G., Suresh S., Adv. Mater., 21, 419-424 (2009).

18) He Z., Liu K., Manaloto E., Casey A., Cribaro G. P., Byrne H. J., Tian F., Barcia C., Conway G. E., Cullen P. J., Curtin J. F., Sci. Rep., 8, 5298 (2018).

19) Ishii M., Fukuoka Y., Deguchi S., Otake H., Tanino T., Nagai N., Int. J. Mol. Sci., 20, pii: E476 (2019). 